\title{
Pemahaman konsep matematika siswa dengan strategi everyone is a teacher here
}

\author{
Dewa Ayu Krisna Apriyanti, I Made Sugiarta, I Made Suarsana \\ Universitas Pendidikan Ganesha, Jl. Udayana No. 11 Singaraja, Bali \\ *apriyantidwayukrisna@gmail.com
}

Received: 15 Mei 2020; Accepted: o9 Juni 2021; Published: 30 Juni 2021

\begin{abstract}
Abstrak
Tujuan dari penelitian ini untuk meningkatkan pemahaman konsep matematika siswa melalui penerapan model pembelajaran kooperatif dengan strategi Everyone is a Teacher Here di kelas VIII E SMPN 4 Sukasada Tahun Ajaran 2019/2020 karena memahami konsep matematika merupakan hal penting serta menjadi kemampuan dasar yang mesti dikuasai siswa supaya dapat mengembangkan kemampuan berpikir matematika tingkat tinggi, namun faktanya kemampuan pemahaman konsep matematika siswa masih rendah. Jenis penelitian ini adalah penelitian tindakan kelas. Instrumen penelitian ini berupa tes pemahaman konsep berbetuk soal uraian dengan 6 pertanyaan di masing-masing siklus dan non tes berupa angket untuk mengetahui tanggapan siswa. Setelah dilaksanakan dengan 3 siklus didapatkan hasil bahwa model pembelajaran kooperatif dengan strategi Everyone is a Teacher Here mampu meningkatkan pemahaman konsep matematika siswa serta siswa menanggapi dengan positif pembelajaran dengan menerapkan model ini.
\end{abstract}

Kata kunci: Pemahaman konsep, Matematika, Strategi Everyone is a Teacher Here

\begin{abstract}
This study aims to improve students' understanding of mathematical concepts through the application of cooperative learning models with the Everyone is a Teacher Here strategy in VIII E class of SMPN 4 Sukasada Academic Year 2019/2O2O because understanding mathematics concepts is important and becomes the basic ability that students must master to develop high-level mathematical thinking skills, but the fact is the ability to understand students' mathematical concepts is still low. This type of research is classroom action research. The instrument in this study was a test of understanding the concept of problemsolving questions consisting of 6 questions in each cycle and non-test in the form of a questionnaire to determine student responses. After being carried out with 3 cycles, the result is the cooperative learning model with Everyone is a Teacher Here strategy can improve students' understanding of mathematical concepts and students respond positively to learning by applying this model.
\end{abstract}

Keywords: Conceptual understanding, Mathematics, Everyone is a Teacher Here Strategy 


\section{PENDAhULUAN}

Matematika merupakan ilmu yang penting untuk dipahami semua orang dan mata pelajaran yang diajarkan di semua jenjang pendidikan, hal itu dikarenakan matematika adalah ilmu dasar yang berperan penting dalam ilmu pengetahuan serta teknologi dan ilmu yang bermanfaat bagi kehidupan sehari-hari (Budarsini et al., 2018; Zahid et al., 2013). Tujuan matematika adalah untuk mempersiapkan peserta didik supaya mereka bisa menggunakan pola pikir dari matematika di kehidupan sehari-harinya serta saat belajar ilmu pengetahuan yang lain (Suherman, 2015). Dalam matematika, pemahaman konsep matematika merupakan hal yang penting dan akan lebih bermakna apabila dibangun oleh siswa sendiri (Hendrayana, 2017; Kesumawati, 2013).

Pemahaman konsep matematika adalah kemampuan yang dimiliki siswa dalam memahami ide-ide abstrak untuk mengklasifikasikan objek-objek atau peristiwaperistiwa dalam matematika (Budarsini et al., 2014). Konsep dalam matematika sendiri bersifat hierarkis karena merupakan ilmu mengenai struktur dan hubungan (Matematika et al., 2014). Kemampuan siswa dalam memahami konsep membuat siswa mampu untuk mengaitkan materi yang telah diajarkan dan yang baru, maka dari itu bila siswa tidak memahami suatu konsep dengan baik maka untuk konsep selanjutnya yang masih terkait akan mengalami kesulitan dalam memahaminya (Made Suarsana et al., 2018). Oleh sebab itu penting untuk memahami konsep dengan baik dalam matematika. Indikator pemahaman konsep mengacu pada 3 indikator yang ditetapkan oleh (NCTM, 2000) yakni: 1) mengemukakan konsep menggunakan kalimat sendiri; 2) menentukan atau memberikan contoh atau non contoh suatu konsep; 3) mengaplikasikan/menggunakan konsep secara tepat di berbagai situasi. Realitanya di lapangan, di sekolah penelitian peneliti khususnya, banyak siswa masih berpikir bahwa matematika susah, menakutkan, tidak menarik, tidak menyenangkan serta membuat bosan. Hal itu terjadi akibat dari rumus serta angka yang banyak yang mesti diingat oleh mereka, lalu siswa di sekolah itu juga mengganggap tidak terlalu berfungsinya matematika di kehidupan sehari-hari sehingga minat siswa belajar matematika kurang.

Biasanya di sekolah, matematika diajarkan masih dengan cara ceramah, tanya jawab dan diberikan penugasan serta medianya pun masih menggunakan media papan tulis saja padahal strategi dalam penyampaian materi merupakan satu dari beberapa hal yang memengaruhi pemahaman serta prestasi siswa (Lasmanah, 2017). Apabila kondisi ini dilanjutkan terusmenerus akan menimbulkan rasa bosan dan kejenuhan, dan akan mengakibatkan pemahaman konsep matematika siswa rendah. Dilihat dari hasil observasi serta wawancara dengan guru pengampu matematika di SMP Negeri 4 Sukasada terdapat gejala-gejala pembelajaran yang diberlakukan masih konvensional, siswa masih kesulitan memahami materi yang dipelajari, guru masih berperan sangat besar atau masih mendominasi, yang menyebabkan siswa kurang terlihat berperan dalam pembelajaran atau bisa dikatakan siswa kurang aktif dalam pembelajaran.

Selain melaksanakan observasi serta wawancara, untuk mengukur tingkat pemahaman konsep siswa, dilakukan juga tes awal terkait pemahaman konsep matematika kepada 33 siswa kelas VIII E, namun hasil tes masih jauh berada di bawah kreteria ketuntasan minimal atau KKM yaitu rata-ratanya 45,5 sedangkan yang ditetapkan sekolah adalah 65 . Dilihat dari tes awal tersebut dan penjelasan dari guru, banyak siswa kesulitan untuk mengungkapkan konsep dengan kata-kata mereka sendiri, mereka juga belum bisa menentukan mana contoh dan yang bukan dari konsep yang mereka pelajari, dalam penggunaan rumus atau konsep, mereka seringkali keliru bahkan tidak mampu untuk 
Peningkatan pemahaman konsep matematika siswa dengan strategi everyone is a teacher here

menjawab pertanyaan mengenai konsep yang dipelajari.

Strategi Everyone is a Teacher Here adalah strategi yang mana siswa diberikan tanggungjawab berperan menjadi guru bagi siswa lainnya, strategi ini memberikan siswa kesempatan untuk menjelaskan atau mempresentasikan materi yang dipelajari kepada siswa lain sehingga siswa dituntut untuk mampu menjelaskan materi dengan kata-kata mereka sendiri agar bisa dipahami dengan baik oleh siswa lain, selain itu siswa juga dilatih untuk membuat pertanyaan pada kartu indeks dan mampu menjawab pertanyaan temannya sehingga siswa akan dilatih untuk menggunakan konsep yang mereka miliki di berbagai situasi untuk menjawab pertanyaan temannya yang mungkin saja pertanyaan tersebut mengenai contoh maupun bukan contoh suatu konsep (Rahmawati \& Fahmi, 2014). Dengan kata lain, ketika proses tersebut terjadi, mereka akan berusaha untuk memahami konsep dengan baik.

Menurut Silberman yang mengatakan bahwa banyak ahli meyakini bahwa suatu ilmu atau pelajaran dapat dipahami dan dikuasai dengan baik ketika pembelajar bisa mengajarkannya ke orang lain. Beberapa penelitian sebelumnya yang relevan ternyata menunjukkan hasil yang positif mengenai pembelajaran menggunakan strategi ini (Sukarsih, 2009; Hidayatul Akbar, Niko Brahmanto, dan Nur Hadi, 2010; Hany Zahira, 2013; Elynda Desy Kusrini, 2014), dan penelitian mengenai pengaruh strategi ini terhadap kemampuan pemahaman konsep matematika siswa (Elisa Handayani, 2016).

Maka dari itu, diterapkanlah model pembelajaran kooperatif dengan ini untuk mengetahui apakah dengan menerapkan model pembelajaran ini dapat meningkatkan pemahaman konsep matematika siswa dan bagaimana tanggapan siswa terhadap penerapannya.

Jurnal Analisa 7 (1) (2021) :13-22

\section{METODE}

Penelitian ini merupakan Penelitian Tindakan Kelas yang secara garis besarnya terdiri dari empat tahapan yaitu perencanaan, pelaksanaan, pengamatan, dan refleksi yang mana semua tahapan tersebut merupakan suatu unsur dalam membentuk sebuah siklus, yaitu dengan satu putaran kegiatan beruntun kemudian kembali ke tahap pertama. Penelitian ini dilaksanakan di kelas VIII E SMP N 4 Sukasada, Kecamatan Sukasada, Kabupaten Buleleng, Bali pada Semester Genap Tahun Ajaran 2019/2020 dari tanggal 22 Januari sampai dengan 13 Maret 2020. Subjek dalam penelitian ini yaitu siswa kelas VIII E SMP N 4 Sukasada sebanyak 35 siswa yang terdiri dari 17 siswa perempuan serta siswa laki-laki sebanyak 18 orang.

Instrumen Penelitian untuk mengukur pemahaman konsep matematika siswa adalah dengan menggunakan tes uraian sebanyak 6 butir soal dengan soal nomor 1 menunjukan indikator 1 yaitu siswa mampu menyatakan konsep dengan kata-kata sendiri, soal nomor 2 menunjukkan indikator 2 yaitu siswa mampu mengidentifikasi atau memberi contoh atau bukan contoh dari konsep dan soal no 3 sampai dengan 6 menunjukkan indikator 3 yaitu siswa mampu menggunakan konsep materi tersebut dengan tepat di segala situasi.

Tabel 1. Sebaran soal Pemahaman Konsep

\begin{tabular}{ccc}
\hline No. Soal & Indikator & Skor Maksimal \\
\hline 1 & 1 & 2 \\
2 & 2 & 2 \\
3 & 3 & 4 \\
4 & 3 & 4 \\
5 & 3 & 4 \\
6 & 3 & 4 \\
\hline
\end{tabular}

Sedangkan untuk mengetahui tanggapan siswa terhadap penerapan strategi ini dalam proses pembelajaran dilakukan dengan memberikan angket pada akhir siklus III. Angket tanggapan siswa pada penelitian ini merupakan tanggapan siswa mengenai keterkaitan, perasaan, serta 
kemudahan memahami komponen pembelajaran.

Pemahaman konsep matematika siswa akan ditentukan dengan analisis deskriptif terhadap jawaban siswa yang tertuang dalam tes yang diberikan di tiap siklusnya. Dari tes tersebut akan dihasilkan data pemahaman konsep matematika yang mana data tersebut dianalisis berdasarkan dari rata-rata skor tes $(\bar{X})$ sebagai berikut.

$$
\bar{X}=\frac{\sum_{i=1}^{n} X_{i}}{n}
$$

(Suharsimi;, 2013)

Keterangan:

$\bar{X} \quad=$ rata-rata skor pemahaman konsep matematika siswa

$\sum_{i=1}^{n} X_{i}=$ jumlah skor pemahaman konsep matematika

$n \quad$ = banyaknya siswa

Selanjutnya data tersebut dikualifikasikan berdasarkan Kreteria Ketuntasan Minimal atau KKM yaitu 65. Selain dilihat dari rata-rata skor, dalam penelitian ini pemahaman konsep matematika siswa juga dilihat dari ketuntasan belajar (KB) siswa secara klasikal.

Sedangkan untuk mengetahui tanggapan siswa akan dilakukan analisis dengan menentukan rata-rata skor tanggapan siswa $(\bar{A})$ sebagai berikut.

$$
\bar{A}=\frac{\sum_{i=1}^{n} A_{i}}{n}
$$

(Candiasa, 2010)

Keterangan:

$\bar{A}=$ rata-rata skor tanggapan siswa

$A_{i}=$ skor tanggapan siswa ke-i

$n$ = banyak siswa

Selanjutnya data tanggapan tersebut dianalisis untuk menentukan kriteria pada Tabel 2.

Tabel 2. Kriteria Tanggapan Siswa

\section{Rentangan Skor}

\begin{tabular}{ll}
\hline $\bar{A} \geq \boldsymbol{M I}+1,8 \boldsymbol{S D I}$ & Sangat \\
$\boldsymbol{M I}+0,6 \boldsymbol{S D I} \leq \overline{\boldsymbol{A}}<\boldsymbol{M I}+1,8 \boldsymbol{S D I}$ & Positif \\
& Positif \\
$\boldsymbol{M I}-0,6 \boldsymbol{S D I} \leq \overline{\boldsymbol{A}}<\boldsymbol{M I}+0,6 \boldsymbol{S D I}$ & Cukup \\
$\boldsymbol{M I}-1,8 \boldsymbol{S D I} \leq \overline{\boldsymbol{A}}<\boldsymbol{M I}-0,6 \boldsymbol{S D I}$ & Negatif \\
$\overline{\boldsymbol{A}}<\boldsymbol{M I}-1,8 \boldsymbol{S D I}$ & Sangat \\
& Negatif
\end{tabular}

Keterangan:

$M I=\frac{1}{2} \underset{\text { minimum ideal })}{\text { (Skor maksimum ideal }}+$ Skor

$S D I=\frac{1}{6} \quad$ (Skor maksimum ideal - Skor minimum ideal).

Penelitian ini dapat dikategorikan berhasil jika pemahaman konsep matematika siswa ada di kategori tuntas, yaitu rata-rata skor pemahaman konsep siswa minimal 65, ketuntasan belajar siswa secara klasikal minimal 85\%, dan tanggapan siswa dengan penerapan model pembelajaran ini bila ditinjau dari rata-ratanya minimal dalam kategori positif.

\section{HASIL DAN PEMBAHASAN}

Pada refleksi awal dilaksanakan wawancara dengan guru matematika di kelas VIII E serta observasi langsung ke kelas VIII E SMP Negeri 4 Sukasada. Dilihat dari hasil wawancara serta observasi/pengamatan dapat disimpulkan bahwa banyak siswa yang pemahaman konsep matematikanya terhadap yang mereka pelajari masih kurang. Untuk lebih meyakinkan terkait kurangnya pemahaman konsep matematika siswa maka dilakukan juga tes awal, dimana tes yang diberikan berupa soal uraian sebanyak 3 buah. Berdasarkan tes awal yang telah dilaksanakan, sebagian besar siswa belum memahami konsep dengan baik, belum dapat menyelesaikan soal sesuai dengan indikator pemahaman konsep matematika berdasarkan 
indikator menurut (NCTM, 200o) yang telah dipaparkan sebelumnya pada pendahuluan. Hasil dari tes awal termasuk rendah karena rata-rata nilai hasil tes masih jauh berada di bawah KKM yaitu 65, itu menandakan bahwa pemahaman konsep matematika siswa kelas VIII E SMP Negeri 4 Sukasada rendah, untuk itu dilakukan perbaikan terhadap proses pembelajaran di kelas tersebut.

Siklus I dilaksanakan dengan empat kali pertemuan, dengan tiga pertemuan pelaksanaan tindakan dan satu pertemuan pelaksanaan tes. Pokok bahasan di siklus I mengenai unsur-unsur lingkaran, keliling dan luas lingkaran dengan tes pemahaman konsep matematikanya terdiri atas 6 butir soal yang berbentuk uraian. Di awal siklus, siswa dikelompokkan menjadi kelompok-kelompok kecil yang terdiri atas 5-6 siswa yang dipilih oleh peneliti sendiri agar heterogen. Karena subjek dalam penelitian ini sebanyak 35 orang, sehingga bisa dibentuk 6 kelompok yang mana ada 5 kelompok dengan 6 siswa/kelompok dan satu kelompok dengan 5 siswa. Kelompok ini tidak akan berubah, jadi akan selalu berlaku untuk setiap pembelajaran berikutnya.

Pada siklus I dilaksanakan tes yang terdiri atas 6 butir soal uraian yang mana untuk indikator 1 ditunjukkan oleh soal nomor 1, indikator 2 ditunjukkan oleh nomor 2, serta untuk indikator 3 ditunjukkan oleh nomor 3,4,5, dan 6. Rata-rata skor untuk indikator 1 adalah 1,26 dengan persentase 62,86\%. Rata-rata skor untuk indikator 2 adalah 1,06 dengan persentase 52,86\%. Rata-rata skor untuk indikator 3 adalah 1,84 dengan persentase $45,9 \%$. Sedangkan secara keseluruhan rata-rata skor pada siklus I adalah 48,29 dan ketuntasan belajar (KB) siswa secara klasikal adalah 14\% karena ada 5 siswa dari 35 siswa yang nilainya tuntas. Namun, sesuai dengan kategori sebelumnya, karena rata-rata nilai ini di bawah KKM (65) dan ketuntasan belajar secara klasikalnya masih di bawah 85\%, sehingga belum memenuhi indikator keberhasilan yang sudah ditetapkan, jadi masih dalam kategori belum tuntas.
Beberapa kendala yang didapat pada pelaksanaan siklus I yaitu siswa yang kurang aktif dalam pembelajaran termasuk diskusi kelompok, kualitas pertanyaan pada kartu indeks kurang, kegiatan belum sesuai dengan waktu sudah dialokasikan, masih sedikit siswa yang berani mengemukakan pendapatnya serta siswa kesulitan mempresentasikan jawabannya di depan kelas. Kendala-kendala tersebut secara umum terjadi karena siswa belum biasa dengan pembelajaran yang dilakukan. Agar kendala tersebut tidak terjadi kembali di siklus berikutnya maka peneliti berdiskusi bersama guru membicarakan mengenai penanganan dan perbaikan pelaksanaan tindakan yang selanjutnya akan diberlakukan di siklus II yaitu antara lain lebih memotivasi siswa untuk aktif saat pembelajaran terutama saat diskusi kelompok serta lebih berani untuk mengemukakan pendapatnya, meminta siswa untuk mencari referensi pertanyaan di sumber lain dan pertanyaan harus berbeda dengan yang dibuat temannya agar pertanyaannya lebih beragam, disiplin waktu, dan meminta siswa mempersiapkan diri dengan lebih baik untuk presentasi dengan cara berusaha untuk lebih memahami materi yang sedang dipelajari.

Tabel 3. Rata-rata skor perindikator di Siklus I

\begin{tabular}{ccc}
\hline Indikator & Rata-rata $(\bar{x})$ & \% \\
\hline 1 & 1,26 & 62,86 \\
2 & 1,06 & 52,86 \\
3 & 1,84 & 45,9 \\
\hline
\end{tabular}

Siklus II juga dilakukan selama empat kali pertemuan, yakni tiga pertemuan pelaksanaan tindakan serta satu pertemuan pelaksanaan tes. Tes di siklus II berupa tes uraian dengan 6 buah soal dengan pokok bahasan yang diuji di siklus II yaitu terkait sudut pusat dan sudut keliling pada lingkaran, panjang busur, serta luas juring.

Berdasarkan hasil refleksi pada siklus sebelumnya, maka dilakukan beberapa tindakan untuk memperbaiki pembelajaran siklus I. Pada siklus II siswa lebih aktif karena guru lebih sering mendatangi setiap kelompok dan memotivasi setiap kelompok untuk berdiskusi dan menggali informasi lebih dalam 
lagi. Kualitas pertanyaan yang dibuat siswa juga sudah mulai membaik, beragam, dan lebih mudah dipahami karena mereka diberikan kesempatan untuk menjawab pertanyaan yang mereka buat lebih dulu. Pembelajaran pada siklus II lebih terstruktur karena siswa mulai memahami tahapan kegiatan pada model pembelajaran ini, sehingga dapat mengoptimalkan waktu yang sudah direncanakan. Siswa juga sudah berani untuk bertanya kepada temannya bila ada hal yang belum mereka pahami terkait apa yang disampaikan oleh siswa yang mempresentasikan jawabannya. Siswa yang mendapatkan kesempatan mempresentasikan jawabannya juga sudah mempersiapkan diri dengan baik.

Pada siklus II diberikan tes dengan 6 buah soal uraian yang mana untuk indikator 1 ditunjukkan oleh soal nomor 1, indikator 2 ditunjukkan oleh nomor 2, serta untuk indikator 3 ditunjukkan oleh nomor 3,4,5, dan 6. Rata-rata skor untuk indikator 1 adalah 1,6 dengan persentase $80 \%$. Rata-rata skor untuk indikator 2 adalah 1,31 dengan persentase $65,72 \%$. Rata-rata skor untuk indikator 3 adalah 2,49 dengan persentase $62,32 \%$. Sedangkan secara keseluruhan rata-rata skor siswa pada siklus II adalah 64,43 dan ketuntasan belajar (KB) siswa secara klasikal adalah 57\% karena ada 20 siswa dari 35 siswa yang nilainya tuntas. Namun, sesuai dengan kategori sebelumnya, karena rata-rata nilai ini di bawah KKM (65) dan ketuntasan belajar secara klasikalnya masih di bawah 85\%, sehingga belum memenuhi indikator keberhasilan yang sudah ditetapkan, jadi masih dalam kategori belum tuntas.

Beberapa kendala yang didapat pada pelaksanaan siklus II yakni masih terdapat siswa yang kurang aktif, kualitas pertanyaan pada kartu indeks kurang, serta masih ada siswa yang kesulitan mempresentasikan jawabannya di depan kelas. Agar kendala tersebut tidak terjadi kembali di siklus berikutnya maka peneliti berdiskusi bersama guru membicarakan mengenai penanganan dan perbaikan yang selanjutnya akan diberlakukan di siklus III yaitu antara lain lebih memperhatikan siswa yang tidak berperan secara aktif selama kegiatan pembelajaran berlangsung serta selalu memberikan motivasi kepada siswa agar berani untuk menyampaikan pendapatnya, meminta siswa untuk berdiskusi terkait pertanyaan yang mereka buat, dan meminta siswa untuk berdiskusi di kelompoknya terkait jawaban dan cara mereka menyampaikannya nanti bila ditunjuk serta meminta siswa untuk lebih memahami materi yang dipelajari karena pertanyaan apa saja bisa disampaikan ketika mereka presentasi.

Tabel 4 .Rata-rata skor perindikator di Siklus II

\begin{tabular}{ccc}
\hline Indikator & Rata-rata $(\bar{x})$ & $\mathbf{\%}$ \\
\hline 1 & 1,6 & 80 \\
2 & 1,31 & 65,71 \\
3 & 2,49 & 62,32 \\
\hline
\end{tabular}

Siklus III dilakukan dengan tiga kali pertemuan yakni dua pertemuan pelaksanaan tindakan serta satu pertemuan pelaksanaan tes dan angket tanggapan siswa. Pokok bahasan yang diuji adalah garis singgung suatu lingkaran. Tes pada siklus III terdiri atas 6 buah soal uraian dan angket berbentuk penyataan sebanyak 15 pernyataan.

Berdasarkan pada hasil refleksi di siklus II maka dilaksanakan perbaikan pada siklus III. Terdapat peningkatan pada pembelajaran di siklus III bila dibandingkan dengan siklus I dan siklus II karena siswa sudah mulai terbiasa menerapkan model pembelajaran ini. Tindakan perbaikan yang dilaksanakan membuat pemahaman konsep siswa terhadap materi yang dipelajari menjadi lebih baik serta salah satu tindakan perbaikan yang dilakukan dan selalu ditekankan adalah dengan pemberian motivasi kepada siswa-siswa yang membutuhkan perhatian lebih, hal itu agar siswa bisa lebih fokus ketika mengikuti pembelajaran.

Pada siklus III diberikan tes dengan 6 buah soal uraian yang mana untuk indikator 1 ditunjukkan oleh soal nomor 1, indikator 2 ditunjukkan oleh nomor 2, serta untuk 
indikator 3 ditunjukkan oleh nomor 3,4,5, dan 6. Rata-rata skor untuk indikator 1 adalah 1,94 dengan persentase 97,14\%. Rata-rata skor untuk indikator 2 adalah 1,51 dengan persentase 75,71\%. Rata-rata skor untuk indikator 3 adalah 2,94 dengan persentase 73,57\%. Sedangkan secara keseluruhan rata-rata skor siswa pada siklus III adalah 76,14 dan ketuntasan belajar (KB) siswa secara klasikal adalah 89\% karena ada 31 siswa dari 35 siswa yang nilainya tuntas. Oleh karena itu, sesuai dengan kategori yang sudah ditetapkan sebelumnya, karena rata-rata nilai ini berada diatas KKM (65) dan ketuntasan belajar secara klasikalnya diatas 85\% yang berarti sudah memenuhi indikator keberhasilan yang sudah ditetapkan.

Tabel 5. Rata-rata skor indikator di Siklus III

\begin{tabular}{ccc}
\hline Indikator & Rata-rata $(\bar{x})$ & \% \\
\hline 1 & 1,94 & 97,14 \\
2 & 1,51 & 75,71 \\
3 & 2,94 & 73,57 \\
\hline
\end{tabular}

Tabel 6. Rangkuman rata-rata skor

\begin{tabular}{cccc}
\hline \multirow{2}{*}{ Tahap } & \multicolumn{3}{c}{ Indikator } \\
\cline { 2 - 4 } & $\mathbf{1}$ & $\mathbf{2}$ & $\mathbf{3}$ \\
\hline Refleksi Awal & 0,85 & 1,03 & 1,76 \\
Siklus I & 1,26 & 1,06 & 1,84 \\
Siklus II & 1,6 & 1,31 & 2,49 \\
Siklus III & 1,94 & 1,51 & 2,94 \\
\hline
\end{tabular}

Bisa dilihat pada Tabel 6, dari refleksi awal setiap indikator mengalami peningkatan, indikator 1 yang awalnya 0,85 meningkat menjadi 1,94 di akhir, indikator 2 dari 1,03 meningkat menjadi 1,51 di akhir dan indikator 3 di awal 1,76 meningkat menjadi 2,94 diakhir.

Tabel 7. Rata-rata pemahaman konsep dan ketuntasan belajar

\begin{tabular}{ccc}
\hline Tahap & Rata-rata & KB(\%) \\
\hline Refleksi Awal & 45,45 & 3 \\
Siklus I & 48,29 & 14 \\
Siklus II & 64,43 & 57 \\
Siklus III & 76,14 & 89 \\
\hline
\end{tabular}

Bisa dilihat pada Tabel 7, bahwa adanya peningkatan di tiap tahapannya, yang awalnya pada refleksi awal rata-rata pemahaman konsep siswa hanya 45,45 dan ketuntasan belajarnya $3 \%$ meningkat menjadi 76,14 dengan ketuntasan belajar siswanya $89 \%$ diakhir.

Sedangkan hasil angket tanggapan siswa untuk indikator keterkaitan yang ditunjukkuan oleh pernyataan nomor 1, 2, 3, 4, 5 didapat rataratanya 19,83 sehingga berkreteria positif, indikator perasaan yang ditunjukkuan oleh pernyataan nomor $6,7,8,9,10$ didapat rataratanya 21,77 sehingga berkreteria sangat positif, dan indikator kemampuan memahami komponen pembelajaran yang ditunjukkuan oleh pernyataan nomor 11, 12, 13, 14, 15 didapat rata-ratanya 20,37 sehingga berkreteria positif.

Tabel 8. Banyak siswa dalam tiap kreteria tanggapan

\begin{tabular}{lc}
\hline Kreteria & Banyak Siswa \\
\hline Sangat Positif & 12 \\
Positif & 23 \\
Cukup & 0 \\
Negatif & 0 \\
Sangat Negatif & 0 \\
\hline
\end{tabular}

Bisa dilihat pada Tabel 8, siswa yang menanggapi secara positif ada 23 siswa dan yang menanggapi sangat positif ada 12 siswa, serta tidak ada yang siswa yang termasuk dalam kreteria selain positif dan sangat positif. Secara keseluruhan rata-rata skor tanggapan siswa adalah 61,97, karena rata-rata skor ini berada pada rentangan skor $51 \leq \bar{A}<63$ maka secara kualitatif tergolong kategori positif.

Berdasarkan hasil penelitian, bisa dilihat bahwa pemahaman konsep siswa kelas VIII E SMP Negeri 4 Sukasada melalui penerapan model ini mengalami peningkatan pada setiap siklusnya, hal tersebut karena strategi ini menuntut siswa untuk lebih memahami materi agar nantinya dapat membuat pertanyaan, menjawab pertanyaan dan mampu mempresentasikan jawaban tersebut dengan baik. Peningkatan tersebut terlihat karena semakin penerapan model ini diperbaiki maka hasil tes pemahaman 
konsep siswa juga semakin baik bahkan peningkatan tersebut terjadi pada tiap indikator dari satu siklus ke siklus selanjutnya. Indikator 1 misalnya, pada siklus I yang rata-ratanya 1,26 dengan persentase $62,86 \%$ meningkat di siklus II menjadi 1,6 dengan persentase $80 \%$ dan peningkatan tersebut kembali terjadi pada siklus III menjadi 1,94 dengan persentase 97,14\%. Pada siklus I siswa belum bisa menyatakan konsep dengan kata-kata sendiri, cenderung sama dengan yang ada di buku, namun di siklus II mereka sudah mulai bisa menyatakan konsep dengan kata-kata sendiri meski ada kalimat yang belum tepat dan di siklus III kemampuan mereka dalam menyatakan konsep dengan kata-kata sendiri semakin baik. Indikator 1 mengalami peningkatan di tiap siklusnya karena dalam penerapan model ini siswa akan diminta menyampaikan konsep dengan kata-kata sendiri ketika kegiatan presentasi berlangsung, yang mana ketika siswa diminta untuk menyampaikan jawabannya, mereka akan memulainya dengan menjelaskan konsep dengan pemahaman mereka sendiri dan harus bisa dimengerti oleh temannya. Hal tersebut akan merangsang siswa untuk memahami materi dengan lebih baik agar ketika presentasi bisa menyampaikan kepada temannya dengan baik, benar dan bisa dipahami oleh yang mendengar. Karena sudah terlatih dan di tiap siklusnya cara siswa menyampaikan jawabannya semakin baik sehingga ketika diberikan tes atau soal yang berindikator 1, siswa sudah terbiasa menjawabnya dengan menggunakan kata-kata sendiri sesuai pemahaman siswa.

Indikator 2 yang pada siklus I rata-ratanya 1,06 dengan persentase 52,86\% meningkat di siklus II menjadi 1,31 dengan persentase $65,71 \%$ dan meningkat lagi di siklus III menjadi 1,51 dengan persentase 75,71\%. Pada siklus I siswa mengalami kesulitan membedakan contoh dan yang bukan suatu konsep, namun di siklus II mereka sudah mulai bisa membedakannya dan di siklus III kemampuan itu semakin baik. Indikator 2 mengalami peningkatang di tiap siklusnya karena ketika kegiatan presentasi, tak jarang akan ada pertanyaan yang menanyakan mengenai contoh dari konsep yang sedang dibicarakan, misalnya pertanyaan mengenai benda apa saja yang permukaannya berbentuk lingkaran? Apakah lapangan balap sepeda termasuk yang permukaannnya berbentuk lingkaran? Siswa diharuskan siap menjawab bila pertanyaan tersebut terlontar dari siswa lain maupun guru, jadi siswa harus memahami yang mana contoh dan bukan contoh konsep dengan baik agar bisa menjelaskannya kepada temannya.

Pada indikator 3 juga terjadi peningkatan dari siklus I 1,84 dengan persentase 45,89\% lalu meningkat di siklus II menjadi 2,49 dengan persentase $62,32 \%$ dan kembali meningkat menjadi 2,94 dengan persentase $73,57 \%$ di siklus III. Di siklus I siswa masih kesusahan dalam menggunakan konsep yang mereka miliki, namun di siklus II mereka sudah mulai memahami penggunaan dari konsep tersebut namun seringkali salah dalam perhitungan dan di siklus III kemampuan mereka dalam menggunakan konsep semakin baik. Indikator 3 mengalami peningkatan di tiap siklusnya karena setelah mengetahui konsep dan memahaminya, tentunya siswa harus bisa mengaplikasikan konsep tersebut di berbagai situasi, ketika siswa mendapat kartu indeks, mereka akan mendapatkan pertanyaan yang harus mereka jawab dengan cara mengaplikasikan konsep yang sudah mereka pelajari, ketika diskusi kelompok mereka akan saling berdiskusi mengenai berbagai macam pertanyaan dan penyelesaiannya sehingga mereka akan jauh lebih paham terkait pengaplikasian konsep yang mereka pelajari di berbagai situasi.

Tabel 9. Rata-rata Pemahaman Konsep Matematika

\begin{tabular}{|c|c|c|c|c|}
\hline \multirow{2}{*}{ Siklus } & \multicolumn{3}{|c|}{ Indikator } & \multirow{2}{*}{ Keseluruhan } \\
\hline & $\mathbf{1}$ & 2 & 3 & \\
\hline I & 1,26 & 1,06 & 1,84 & 48,29 \\
\hline II & 1,6 & 1,31 & 2,49 & 64,43 \\
\hline III & 1,94 & 1,51 & 2,94 & 76,14 \\
\hline
\end{tabular}

Dengan skor maksimum masing-masing indikator di tiap siklusnya yaitu indikator 1 skor 
maksimumnya 2, indikator 2 skor maksimumnya 2, dan indikator 3 skor maksimumnya 4. Di siklus I, rata-rata skor siswa sebesar 48,29 lalu pada siklus II mengalami peningkatan menjadi 64,43 dan pada akhir siklus III rata-rata skor pemahaman konsep matematika siswa meningkat menjadi 76,14. Ketuntasan belajar siswa secara klasikal juga meningkat dari siklus satu ke siklus selanjutnya. Dari siklus I yang ketuntasan belajar secara klasikalnya adalah 14\% lalu pada siklus II menjadi 57\% dan di siklus terakhir mengalami peningkatan kembali menjadi $89 \%$.

Melalui perbaikan yang telah dilaksanakan selama kegiatan penelitian seperti lebih memotivasi siswa untuk aktif dan berani mengemukakan pendapatnya serta lebih giat dalam belajar, membuat siswa bisa paham dengan konsep matematika, hingga di siklus III tidak terdapat kendala yang berarti dan sudah sesuai dengan harapan yang direncanakan hingga pada akhirnya pada siklus III diperoleh rata-rata skor melebihi rata-rata KKM dan ketuntasan belajar siswa secara klasikal melebihi $85 \%$ serta tanggapan siswa yang didapat dari angket juga menunjukan hasil positif. Hasil penelitian yang didapat sejalan dan melengkapi penelitian yang dilaksanakan oleh (Handayani, 2016) yang penelitiannya menghasilkan bahwa penerapan strategi ini memiliki pengaruh positif terhadap kemampuan pemahaman konsep matematika siswa.

\section{KESIMPULAN}

Berdasarkan hasil penelitian dapat disimpulkan bahwa penerapan model pembelajaran kooperatif dengan strategi ini mampu meningkatkan pemahaman konsep matematika siswa kelas VIII E SMP Negeri 4 Sukasada. Dari siklus I ke siklus II terjadi peningkatan rata-rata skor pemahaman konsep matematika siswa dan ketuntasan belajar siswa secara klasikal, lalu terjadi peningkatan lagi dari siklus II ke siklus III pada rata-rata skor pemahaman konsep matematika siswa serta ketuntasan belajar siswa secara klasikal. Tanggapan siswa terhadap penerapan strategi ini juga ada dalam kategori positif berdasarkan hasil di Tabel 9. Oleh karena itu, penelitian ini dinyatakan berhasil. Bagi pembaca yang memiliki minat untuk meneliti lebih lanjut sebagai penyempurnaan mengenai model ini agar memperhatikan permasalahan yang peneliti temui selama penelitian sebagai bahan pertimbangan.

\section{REFERENSI}

Budarsini, K. P., Suarsana, I. M., \& Suparta, I. N. (2018). Model diskursus multi representasi dan kemampuan pemahaman konsep matematika siswa sekolah menegah pertama. Pythagoras: Jurnal Pendidikan Matematika, 13(2), 110-118.

Candiasa. (2010). Pengujian Instrumen Penelitian Disertai Aplikasi ITEMAN Dan BIGSTEPS.

Handayani, E. (2016). Pengaruh penerapan strategi pembelajaran everyone is a teacher here dengan metode mind map terhadap pemahaman konsep matematis peserta didik kelas VII MTs Negeri o1 Kotabumi tahun ajaran 2015/2016.

Hendrayana, A. (2017). Pengaruh pembelajaran pendekatan rigorous mathematical thinking (RMT) terhadap pemahaman konseptual matematis siswa SMP. Jurnal Riset Pendidikan Matematika.

Kesumawati, N. (2013). Delta-Pi: Jurnal Matematika dan Pendidikan Matematika Vol. 2, No. 1, April 2013 ISSN 2089-855X. Kemampuan komunikasi dan berpikir logis matematik serta kemandirian belajar: eksperimen terhadap siswa sma menggunakan pembelajaran berbasis masalah dan strategi think-talk-write.

Lasmanah, A. (2017). Peningkatan hasil belajar matematika siswa melalui model kooperatif teknik think pair share (tps) (penelitian tindakan kelas terhadap siswa kelas VII-A SMPN Sukasari Sumedang”. Jurnal Analisa, 2(3), 18.

Made Suarsana, I., Widiasih, N. P. S., \& Nengah 
Suparta, I. (2018). The effect of brain based learning on second grade junior students' mathematics conceptual understanding on polyhedron. Journal on Mathematics Education.

Matematika, J. D., Matematika, J., \& Negeri, U. (2014). Pembelajaran matematika sekarang dan yang akan datang berbasis karakter. Didaktik Matematika, 1(2), 3042.

NCTM. (2000). Principles and Standards for School Mathematics. In School Science and Mathematics.

Rahmawati, I., \& Fahmi, S. N. (2014). Implementasi metode everyone is teacher here pada pembelajaran tematik terintegrasi kelas IV semester ii subtema sikap kepahlawanan SD Petompon 01 Semarang. Malih Peddas (Majalah Ilmiah Pendidikan Dasar).

Silberman, M. (1996). Introduction to active learning. Active Learning: 101 Strategies to Teach Any Subject.

Suharsimi; A. (2013). Dasar-Dasar Evaluasi Pendidikan. In Jakarta: Bumi Aksara.

Suherman. (2015). Kreativitas siswa dalam memecahkan masalah matematika materi pola bilangan dengan pendekatan matematika realistik (pmr). Al-Jabar.

Zahid, A., Susilawati, W., Jihad, A., \& Maryono, I. (2013). Penerapan teknik ikonik terhadap kemampuan pemahaman matematika siswa pada pembelajaran matematika pokok bahasan pecahan. Jurnal Analisa, 1(1), 12-19. 